\title{
Syntopic Cystoseira taxa support different molluscan assemblages in the Gulf of Naples (southern Tyrrhenian Sea)
}

\author{
Antonia Chiarore $^{\mathrm{A}}$, Iacopo Bertocci ${ }^{\mathrm{B}, \mathrm{C}}$, Sara Fioretti ${ }^{\mathrm{A}}$, Angela Meccariello ${ }^{\mathrm{D}}$, Giuseppe \\ Saccone $^{\mathrm{D}}$ and Fabio Crocetta ${ }^{\mathrm{B}, \mathrm{E}}$, Francesco Paolo Patti ${ }^{\mathrm{A}, \mathrm{E}, \mathrm{F}}$
}

\begin{abstract}
${ }^{A}$ Department of Integrative Marine Ecology, Stazione Zoologica Anton Dohrn, Benthos Ecology Center - Villa Dohrn, I-80077 - Ischia, Italy; ${ }^{\mathrm{B}}$ Department of Integrative Marine Ecology, Stazione Zoologica Anton Dohrn, Villa Comunale, I-80121 - Napoli, Italy; ${ }^{\mathrm{C}}$ Department of Biology, University of Pisa, CoNISMa, via Derna 1, I-56126 - Pisa, Italy; ${ }^{\mathrm{D}}$ Department of Biology, University of Naples "Federico II", I-80126 - Napoli, Italy. ${ }^{\mathrm{E}}$ These authors are listed in alphabetical order and equally contributed to the present article. ${ }^{\mathrm{F}}$ Corresponding author: francesco.patti@szn.it.
\end{abstract}

\footnotetext{
Abstract. Brown macroalgae belonging to the genus Cystoseira (Fucales: Sargassaceae) are canopy-forming organisms whose recent decline at basin and local scale has been widely documented, which urgently calls for research to fill knowledge gaps and support new and effective measures for protection. We hereby characterized the molluscan assemblages associated with three Cystoseira taxa (C. amentacea, $C$. compressa, and $C$. crinita) from Ischia Island (Italy, Tyrrhenian Sea), and tested whether different congeneric taxa may syntopically support a different biota. In particular, these assemblages were compared among three Cystoseira species, two times of sampling (June-July 2015 and June-July 2016), and six sites in terms of multivariate structure (identity and relative abundances of constituting taxa combined, and presence-absence composition), as well as for synthetic measures of diversity, including the total richness of taxa, the exponential Shannon index, and the reciprocal Simpson
} 
index. A total of 24736 molluscan individuals were collected, overall belonging to 52 taxa. The majority of the identified species included micrograzers and filter feeders, in agreement with similar previous studies. The composition of associated molluscan assemblages, which was mainly represented by juvenile individuals, differed among the three Cystoseira species, suggesting that even congeneric taxa do not support an analogous benthic fauna. The present findings shed light on the molluscan biota associated with Cystoseira taxa in the Gulf of Naples and strengthen the importance of such habitat-forming macroalgae in structuring the local infralittoral invertebrate biodiversity and as a nursery for species-specific associated molluscs.

Additional keywords: Mediterranean Sea, infralittoral fringe, canopy-forming algae, nursery area, algae-specific assemblages.

\section{Introduction}

Marine seaweeds and seagrasses are important benthic primary producers worldwide (Mann 1973). In the Mediterranean Sea, especially in areas not subject to intense anthropogenic disturbance, species belonging to the order Fucales Bory de Saint-Vincent dominate on rocky substrates from the upper infralittoral to the upper circalittoral shore level, establishing structurally complex habitats, supporting diversified assemblages, and functioning as ecological engineers (Ballesteros 1992; Giaccone et al. 1994; Schiel and Foster 2006; Cormaci et al. 2012; Poursanidis et al. 2019). In particular, Cystoseira C. Agardh and Sargassum C. Agardh taxa are long-living macroalgae with a complex tridimensional structure, providing habitat, food, shelter, and nursery for a wide variety of species (Ballesteros 1992; Bulleri et al. 
Cheminée et al. 2013). They are also considered of special concern within the European Water Framework Directive (WFD, 2000/60/EC), where they are listed as coastal water quality indicators (Orfanidis et al. 2001; Ballesteros et al. 2007; Orfanidis 2007). Unfortunately, most of the Cystoseira assemblages in the Mediterranean Sea are declining, when not even disappearing completely, in response to cumulative impacts, including habitat destruction, eutrophication, water turbidity, out-competition by non-indigenous species, and human trampling (Thibaut et al. 2005; Iveša et al. 2016; Blanfuné et al. 2016; Gianni et al. 2017; Falace et al. 2018). Consequently, they may be substituted by less structured and opportunistic species, such as turf-forming filamentous seaweeds, mussels, or sea urchin-driven barrens. This shift may lead not only to an overall simplification of the architectural complexity of the dominant biological habitat, but also to the loss of their associated epibenthic diversity (Benedetti-Cecchi et al. 2001; Micheli et al. 2005; Thibaut et al. 2005, 2015; Mangialajo et al. 2008; Perkol-Finkel and Airoldi 2010; Sala et al. 2012; Buia et al. 2013; Grech et al. 2015; Mancuso et al. 2018).

Amongst the invertebrate fauna inhabiting Cystoseira associations, Mollusca were widely studied and often found to be among the most highly represented and dominant taxa, being also considered an important food source for higher trophic levels (Milazzo et al. 2000; Chemello and Milazzo 2002; Pitacco et al. 2014; Poursanidis et al. 2016; Piazzi et al. 2018; Lolas et al. 2018). However, despite the long-lasting marine and malacological research in the Gulf of Naples (Tyrrhenian Sea), little is known on the molluscan fauna associated with such canopy-forming algae in the same area. Therefore, taking also into account the wide historical changes locally reported for Cystoseira taxa in the infralittoral zone, as well the loss of their natural habitats and the ongoing coastal transformation (Grech et al. 2015), empirical investigations of such assemblages are urgently needed. In this context, the main aims of this study were: i) to obtain a qualitative and quantitative characterization of the molluscan assemblages associated with Cystoseira belts around Ischia Island, i.e., the only portion of the 
Gulf of Naples where these complex tridimensional structures still persist; ii) to test whether different congeneric taxa may support different molluscan assemblages syntopically, according to peculiar species-specific traits of the habitat-forming Cystoseira host taxon. Eventually, the obtained information would contribute to filling a knowledge gap regarding the ongoing biodiversity changes in the Mediterranean Sea and to confirming the importance of macroalgal biogenic habitats as preferential areas for the recruitment of molluscs.

\section{Materials and methods}

\section{Study area}

Ischia is a volcanic island located in the Gulf of Naples, southern Tyrrhenian Sea (Mediterranean Sea). It is the largest of the Phlegraean Islands, with about $34 \mathrm{~km}$ of coastline and an area of $46.3 \mathrm{~km}^{2}$. In 2007, it was included in the Regno di Nettuno marine protected area (MPA), together with Procida and Vivara Islands. The northern side is characterized by low rocky coasts and few sandy beaches, and hosts the main harbor that daily connects the island with the mainland. In addition, it has the highest percentage of coastal artificial structures in the whole island. The western side is delimited by Punta Caruso and Punta Imperatore, and is characterized by high rocky coasts and two wide sandy beaches. The coastal morphology of the southern side is mainly characterized by cliffs, but also by the largest sandy beach of the island, namely Maronti. The eastern side is morphologically similar to the northern one, with low rocky coasts and some small sandy beaches.

\section{Sampling design and collection of data}

The study was carried out at six sampling sites distributed around Ischia Island: CA - Castello

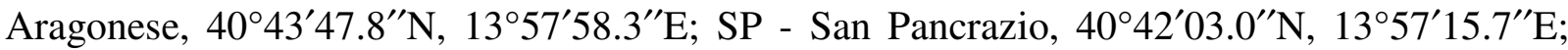




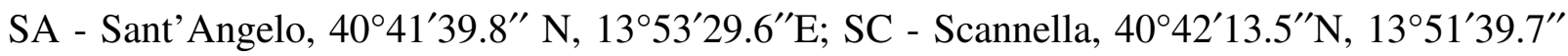

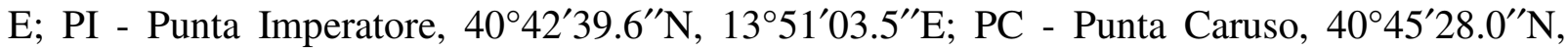
$13^{\circ} 51^{\prime} 45.2^{\prime \prime} \mathrm{E}$; see Fig. 1). These sites have comparable physical features, such as substrate slope (ranging from 0 to 30 degrees) and hydrodynamics (mid to high exposed rocky shores), and were selected according to the known presence of infralittoral fringes dominated by Cystoseira taxa, namely Cystoseira amentacea (C. Agardh) Bory de Saint-Vincent, Cystoseira compressa (Esper) Gerloff \& Nizamuddin and Cystoseira crinita Duby (Buia et al. 2013). The six sampling sites spanned the entire coastline, with the exception of the northern side, where few scattered or even no Cystoseira individuals were recorded.

The sampling was carried out by snorkelling during June-July 2015 and June-July 2016, corresponding to the late spring/early summer period when Cystoseira's thalli show the maximum development, before starting to lose the secondary branches (Ballesteros 1992; Hoffmann et al. 1992; Falace et al. 2005; Sales and Ballesteros 2012). Based on the methodology already used by several authors (e.g. Boudouresque and Belsher 1979; Ballesteros 1992; Bianchi et al. 2003), three $20 \times 20 \mathrm{~cm}$ quadrats (a few metres apart) were randomly selected at each site. After a visual counting of the total number of thalli of each Cystoseira species, all organisms in each quadrat were collected by scraping, sealed in plastic bags, and preserved in a cool box for subsequent analysis in the laboratory.

\section{Laboratory processing of samples}

Upon arrival to the laboratory, the density of Cystoseira in each replicate quadrat was estimated as the number of thalli per $400 \mathrm{~cm}^{2}$. Cystoseira's thalli were then carefully rinsed in seawater to separate the associated fauna. The length of each thallus was measured from the base of the holdfast to the distal tip of the frond (Falace et al. 2005) and the obtained data were used to calculate the mean size of the thalli of each species in each replicate. The biomass of 
each Cystoseira species per quadrat was assessed as dry weight, after drying the thalli at $60^{\circ} \mathrm{C}$ for 60 hours.

The Cystoseira-associated fauna was sieved through a $0.5 \mathrm{~mm}$ mesh and subsequently preserved in $70 \%$ ethanol for further taxonomic determination. Molluscs were sorted out with a stereomicroscope and determined to the lowest possible taxonomic level, mostly using the identification keys of Scaperrotta et al. (2009-2016), Gofas et al. (2012), and Trainito and Doneddu (2014). They were subsequently counted, listed according to the updated taxonomy and nomenclature of the World Register of Marine Species database (WoRMS Editorial Board 2018), and assigned to different feeding guilds (FG) following Solis-Weiss et al. (2004), Rueda et al. (2009), and Gofas et al. (2012). The following categories were considered: C - carnivores feeding on other mobile organisms (predators); D - deposit feeders feeding on organic particles contained in the sediment; E - ectoparasites and specialised carnivores feeding on much larger organisms on which they live during their life cycle; FF - filter feeders capturing the particles in the water column with their gills and/or with mucous strings; MG - micrograzers and/or mesograzers feeding on microalgae, cyanobacteria or detritus attached to algal fronds; AG grazers of macroalgae.

\section{Statistical analyses}

Differences in the percentage cover, biomass, number of thalli, and thallus length of each Cystoseira species between two times and among six sampling sites were tested with three-way analysis of variance (ANOVA), including the following crossed factors: 'Time' (random, two levels: June-July 2015 and June-July 2016), 'Cystoseira species' (fixed, two levels: $C$. compressa, C. amentacea, and C. crinita), and 'Site' (random, six levels: Castello Aragonese, San Pancrazio, Sant'Angelo, Scannella, Punta Imperatore, and Punta Caruso). The three quadrats sampled within each site at each time provided the replicates for this analysis. The 
same type and model of analysis was used to test for differences in the total richness, the exponential Shannon index, and the reciprocal Simpson index.

Before each ANOVA, the homoscedasticity assumption was checked with Cochran's $C$ test and data were transformed when necessary. When heterogeneity of variances could not be removed by transformation, the analysis was performed on untransformed data. Results were considered robust if not significant $(\mathrm{p}>0.05)$, since the probability of Type II error is not affected by heterogeneous variances, or significant at $\mathrm{p}<0.01$, to compensate for increased probability of Type I error (Underwood 1997). Relevant post-hoc comparisons of levels of significant factors were done using the Student-Newman-Keuls (SNK) test.

A three-way permutational multivariate analysis of variance (PERMANOVA, Anderson 2001) based on the same model of ANOVA and on Bray-Curtis dissimilarities was used to test for differences in the composition of molluscan assemblages associated with each Cystoseira species between times of sampling and among sites. To separate differences due to the identity and relative abundance of taxa that are combined by Bray-Curtis dissimilarities, this analysis was repeated using either the matrix of raw abundances, or that of presence $v s$. absence data as input. When relevant, Student's pair-wise $t$-tests were used for post-hoc multivariate comparisons.

The SIMPER procedure (Clarke 1993) based on presence-absence data was performed to calculate the absolute $\left(\delta_{\mathrm{i}}\right)$ and percentage $\left(\delta_{\mathrm{i}} \%\right)$ contribution of each molluscan taxon to the total within-sample dissimilarity of the assemblage associated with each Cystoseira species, using $90 \%$ of cumulative dissimilarity as cut-off to exclude low contributions.

Finally, the cumulative ranked species abundance (or $k$-dominance) curves were computed to extract information on relative species abundance associated with the three Cystoseira species (Clarke 1990). 


\section{Results}

\section{Macroalgal features}

The three Cystoseira species differed in percentage cover, biomass, and number of thalli depending on the sampled site (Table 1). Cystoseira amentacea and C. compressa, in particular, showed dense belts at all sampling sites, while $C$. crinita co-occurred with the other two species only at a single site, namely Scannella (Fig. 2A). At this site, however, all such abundance-related variables were comparable among the three macroalgal species (Fig. 2A, 2B, 2C-a). At the Castello Aragonese and Punta Caruso sites, instead, both the percentage cover and the individual abundance of $C$. compressa were larger compared to $C$. amentacea, while no differences in such variables between the same species occurred at the other sites (Fig. 2A, 2C-a). Analogously, C. compressa and C. amentacea showed comparable biomass at all sites (Fig. 2B). Moreover, a significant 'Time $\times$ Cystoseira species' interaction was detected for the abundance of thalli (Table 1), being higher for $C$. compressa than for $C$. amentacea in June-July 2015, but not in June-July 2016, and obviously lower for $C$. crinita compared to the other two Cystoseira species (Fig. 2C-b).

Finally, the differences in thallus length among $C$. compressa, $C$. amentacea, and $C$. crinita were also temporally and spatially variable (Table 1). Where the three species cooccurred, in June-July 2015 C. crinita was larger than both $C$. compressa and C. amentacea, while one year after $C$. compressa was significantly smaller than the other two species (Fig. 3). Where only two species co-occurred, $C$. amentacea was larger than $C$. compressa at all sites sampled in June-July 2015. In June-July 2016, the same pattern was shown only at two sites, i.e., San Pancrazio and Punta Caruso (Fig. 3). 
Assemblage structure and species diversity of Cystoseira-associated molluscan fauna

A total of 24736 molluscan individuals were collected, belonging to 52 different taxa, three classes, and 29 families (Table 2). Most of the identified taxa were micrograzers (32 species) and filter feeders (11 species). In addition, five nudibranch taxa of specialized carnivores [Hancockia uncinata (Hesse, 1872), Doto cervicenigra Ortea \& Bouchet, 1989, Doto rosea Trinchese, 1881, Eubranchus cf. tricolor Forbes, 1838, and Trinchesia sp.], two species of carnivores [Pisania striata (Gmelin, 1791) and Raphitoma sp.], one species of macroalgal grazer (Aplysia cf. parvula Mörch, 1863), and one species of deposit feeder [Sinezona cingulata (O. G. Costa, 1861)] were found. However, most of the collected individuals were juveniles. Gastropoda Cuvier, 1795 was the class represented by the highest number of families and species (22 and 41, respectively), followed by Bivalvia Linnaeus, 1758 (six and nine), and Polyplacophora Gray, 1821 (one and two). The most represented families were Rissoidae Gray, 1847 (10 species) and Trochidae Rafinesque, 1815 (five species) among gastropods, and Mytilidae Rafinesque, 1815 (four species) among bivalves. Bivalvia was the most abundant class, accounting for 24110 individuals, followed by Gastropoda with 622 individuals, and by Polyplacophora with four individuals $(97.5 \%, 2.5 \%$, and $0.02 \%$ of the total abundance, respectively). Within bivalves, however, Mytilus galloprovincialis Lamarck, 1819 alone accounted for 23654 individuals, contributing $95.6 \%$ to the total abundance, and it was also found in association with all the three Cystoseira taxa at all six sampling sites. Among the other molluscan species, Eatonina pumila (Monterosato, 1884), Thylaeodus rugulosus (Monterosato, 1878), Musculus costulatus (Risso, 1826), Doto cervicenigra Ortea \& Bouchet, 1989 and Mytilaster solidus Monterosato, 1883 showed the highest dominance indexes $(12.38 \%, 6.93 \%, 28.92 \%, 11.18 \%$ and $10.91 \%$, respectively). Doto cervicenigra, however, was only found associated with $C$. amentacea and $C$. compressa, while the other species were shared among all three Cystoseira species. A total of 44 species (35 Gastropoda, seven 
Bivalvia, and two Polyplacophora) were associated with C. amentacea, providing $59.5 \%$ of the total abundance. Among them, M. costulatus was the most frequent (88.9\%) and abundant (37.8\%), followed by E. pumila (72.2\% of frequency, $13.7 \%$ of abundance). A total of 27 species (19 Gastropoda, seven Bivalvia, and one Polyplacophora) were associated with $C$. compressa, representing $39.5 \%$ of the total abundance. The most frequent $(58.3 \%)$ and abundant $(23.8 \%)$ of these was $M$. solidus, followed by M. costulatus (52.8\% of frequency, $16.2 \%$ of abundance), E. pumila (47.2\% of frequency, $9.9 \%$ of abundance), and T. rugulosus (39\% of frequency, $18.5 \%$ of abundance). A total of 22 species (17 Gastropoda, four Bivalvia, and one Polyplacophora) were associated with $C$. crinita, contributing $1.0 \%$ to the total abundance. Out of these, T. rugulosus was the most frequent (88.3\%), followed by S. cingulata and Barleeia unifasciata (Montagu, 1803) (66.7\% of frequency each). The most abundant $C$. crinita-associated species, however, was Columbella rustica (Linnaeus, 1758) (21.8\%).

The three Cystoseira-associated assemblages shared a total of 12 species, including eight Gastropoda, three Bivalvia, and one Polyplacophora (Table 2). The species exclusively associated with one or two algal species were as follow: six species exclusive of $C$. compressa (four Gastropoda and two Bivalvia), 17 species exclusive of $C$. amentacea (14 Gastropoda, two Bivalvia, one Polyplacophora), and one species, belonging to the Steromphala adansonii (Payraudeau, 1826) complex, exclusive of $C$. crinita. A total of seven molluscan species were shared between $C$. compressa and $C$. amentacea (six Gastropoda and one Bivalvia), seven species were shared between $C$. amentacea and $C$. crinita, while Clanculus jussieui (Payraudeau, 1826) and Cardita calyculata (Linnaeus, 1758) were shared between $C$. compressa and C. crinita.

A significant 'Time $\times$ Cystoseira species $\times$ Site' interaction was detected by PERMANOVA based on untransformed data (Table 3). This result, however, was mainly driven by obvious differences, though variable in their extent among sampling times and sites, due to the lack of $C$. crinita at all, but one, sites. Where the three Cystoseira species coexisted 
(Scannella site), their associated molluscan assemblages were comparable in June-July 2015 (C. compressa vs. C. amentacea: $t=0.82, \mathrm{p}=0.523 ;$. compressa vs. $C$. crinita: $t=0.70, \mathrm{p}=$ 0.605; C. amentacea vs. C. crinita: $t=0.76, \mathrm{p}=0.575)$, while they differed between $C$. amentacea and $C$. crinita in June-July 2016 (C. compressa vs. $C$. amentacea: $t=1.96, \mathrm{p}=$ 0.102; C. compressa vs. C. crinita: $t=1.26, \mathrm{p}=0.259 ;$ C. amentacea vs. $C$. crinita: $t=3.82, \mathrm{p}$ $=0.004)$. The only other significant difference was in June-July 2016 between $C$. compressaand $C$. crinita-associated assemblages at Punta Imperatore $(t=1.97, \mathrm{p}=0.040)$.

The multivariate analysis repeated based on presence-absence data revealed a significant 'Cystoseira species $\times$ Site' interaction (Table 3). No specific differences apart from those related to the absence of $C$. crinita from five sites were found, while at Scannella the species composition of molluscan assemblages associated with the three Cystoseira species were all comparable (C. compressa vs. C. amentacea: $t=1.01, \mathrm{p}=0.520 ;$ C. compressa vs. C. crinita: $t$ $=1.01, \mathrm{p}=0.489 ;$ C. amentacea vs. C. crinita: $t=1.18, \mathrm{p}=0.347)$.

Independently of the sampling time, the richness of associated molluscs differed spatially between $C$. compressa and $C$. amentacea, being higher for $C$. amentacea at Castello Aragonese and Sant'Angelo (Table 4; Fig. 4A). Where the three macroalgal species coexisted, they supported comparably rich associated assemblages of molluscs (Fig. 4A).

Both the Shannon $\left(\mathrm{H}^{\prime}\right)$ and the reciprocal Simpson (1/D) indexes varied interactively with the sampling time, the host Cystoseira species, and the site (Table 4). Specifically, at San Pancrazio in June-July 2015, C. amentacea-associated assemblages were characterized by a larger value of $\mathrm{H}^{\prime}$ compared to $C$. compressa, while the opposite pattern was shown at Punta Caruso. In June-July 2016, at Scannella H' was higher for C. crinita-associated assemblages compared to the assemblages associated with the other two co-occurring Cystoseira species (Fig. 4B). The reciprocal Simpson index was consistently comparable between the two or the three coexisting macroalgae in June-July 2016, while one year after, at Scannella, it was higher for C. crinita compared to both C. compressa and C. amentacea (Fig. 4C). 
The Mediterranean black mussel Mytilus galloprovincialis dominated the three Cystoseira-associated assemblages at all sites. As a consequence, it provided the highest contribution to the dissimilarity of samples belonging to each macroalga (Table 5). Adding to M. galloprovincialis, four other species, namely M. solidus, M. costulatus, E. pumila, and S. cingulata, were the main characteristic of assemblages associated with each Cystoseira species, although with varying contributions. The molluscan assemblages associated with both $C$. amentacea and $C$. crinita were also characterized by $T$. rugosus, while Dendropoma cristatum accounted for a considerable proportion of dissimilarity within $C$. crinita assemblages only (Table 5).

Consistently with the disproportionate large abundance of $M$. galloprovincialis, the $k$ dominance curves including this taxon showed high initial values of dominance and quickly reached the asymptote (Fig. 5A, 5C, 5E). When M. galloprovincialis was excluded, instead, the same curves displayed low initial values of dominance and slowly reached the asymptote (Fig. $5 \mathrm{~B}, 5 \mathrm{D}, 5 \mathrm{~F})$.

\section{Discussion}

Molluscan assemblage associated with Cystoseira algae at Ischia Island

Molluscan assemblages associated with Cystoseira beds have been the subject of studies in several regions from the western to the eastern Mediterranean since the mid-1900s, due to the recognized importance of these canopy-forming algae in shaping and supporting local biodiversity (Bellan-Santini 1962, 1964, 1969; Zavodnik 1965; Kokataş 1978; Tiganus 1984; Poulicek 1985; Chemello 1986; Menioui 1992a, 1992b; Ergen and Çinar 1994; Russo 1997; Milazzo et al. 2000; Chemello and Milazzo 2002; Bedini et al. 2014; Mačić and Svirčev 2014; Pitacco et al. 2014; Lolas et al. 2018; Piazzi et al. 2018). In the Gulf of Naples, however, the historically most investigated habitat-forming species were Posidonia oceanica (Linnaeus) 
Delile and Cymodocea nodosa (Ucria) Ascherson (Russo et al. 1983; Mazzella et al. 1989, 1992; Gambi et al. 1992, 1996; Scipione et al. 1996; Gambi 2002), with few recent exceptions represented by Corallinales taxa and Sargassum vulgare (Agardh) (Massa-Gallucci et al. 2006; Chiarore and Patti 2013). Therefore, our pioneer study contributes to filling a knowledge gap on the invertebrate fauna locally associated with habitat-forming taxa of the genus Cystoseira.

The examined molluscan assemblage included a relatively high number of taxa (52) belonging to three different classes and quite diverse trophic groups. These results are generally in agreement with previous studies (Zavodnik 1965; Bellan-Santini 1969; Kocatas 1978; Chemello 1986; Menioui 1992a; Chemello and Milazzo 2002; Lolas et al. 2018), as the number of molluscan species reported as living within Cystoseira beds usually varied from $\sim 20$ (Bellan-Santini 1962, 1964, 1969; Ergen and Çinar 1994; Russo 1997; Bedini et al. 2014) to 70-100 (Poulicek 1985; Pitacco et al. 2014; Piazzi et al. 2018), with extreme values of five taxa reported by Mačić and Svirčev (2014) and 161 taxa reported by Milazzo et al. (2000). The former study, however, only investigated macro-epiphytes, whilst the latter one investigated photophilic assemblages as a whole, although largely dominated by Cystoseira. These may be the main reasons for their discrepancy compared to other Mediterranean studies.

Making comparisons with the literature is often challenging due to, among others, the natural variability among geographic areas, the different sampling methods adopted, and the level of taxonomic expertise of the authors. Nevertheless, some similarities between this and previous studies are noticeable. For instance, at the Class level, the trend here observed is consistent with the widely reported evidence of Gastropoda as the dominant Cystoseiraassociated taxon in terms of species number, followed by Bivalvia and Polyplacophora. The same holds for the photophilic algae association as a whole. Although such a ranking also reflects the typical numerical pattern of molluscan biodiversity in the Mediterranean Sea (Templado and Villanueva in Coll et al. 2010), the limited presence of available substrates for burrowing bivalves suggests that their low diversity is not just a taxonomic artifact. At the 
Family level, the two species-richest taxa (Rissoidae and Trochidae) were mostly represented by grazers feeding preferentially on diatoms and epiphyte microalgae of Cystoseira fronds, consistent with previous studies (e.g., Bellan-Santini 1964; Kocatas 1978; Poulicek 1985; Chemello 1986; Chemello and Milazzo 2002). Finally, many of the present Cystoseiraassociated species were analogous to those described by previous research, such as the grazers Acanthochitona fascicularis (Linnaeus, 1767), Tricolia pullus (Linnaeus, 1758), and Columbella rustica (Linnaeus, 1758). Noteworthy, Mytilidae accounted for the third speciesrich taxon, with Mytilus galloprovincialis being the most frequent and the dominant species of the molluscan assemblages studied here. More specifically, only juveniles $(0.3-3 \mathrm{~mm}$ total height) were found within the algal canopies, whilst adult individuals were mostly observed attached to the rock among/below the holdfasts of macroalgae, where they may compete for space with the infralittoral algal associations (Gros 1978; Benedetti-Cecchi and Cinelli 1996; Benedetti-Cecchi et al. 1996). To the best of our knowledge, no mussel-dominated biota was ever reported within Cystoseira beds in the Mediterranean Sea. This would suggest the general lack of a strict association between such algae and molluscan assemblages, and that the Cystoseira-associated fauna may be also influenced by external factors operating on a regional scale.

Finally, the three habitat-forming algae analyzed mostly hosted juveniles of the majority of the associated molluscs, not only of mussels. This confirms the importance of Cystoseira species not only in structuring the local infralittoral invertebrate biodiversity in general, but also as a nursery area for molluscs (Thibaut et al. 2005; Pitacco et al. 2014).

Species-specific assemblages in syntopic Cystoseira taxa

The examined Cystoseira beds differed in terms of architectural attributes. In particular, $C$. compressa and $C$. amentacea, the most widespread species, showed the highest density and 
height, respectively. Indeed, C. compressa is usually smaller than C. amentacea. On the other hand, $C$. crinita only occurred closer to the sea surface at Scannella, where it also completely covered the walls of rock-pools (A. Chiarore, pers. obs.). Where present, however, it dominated in height over the other Cystoseira species. Differences among habitat-forming macroalgae, in terms of associated biota, were reported worldwide, since patterns of abundance and size structure of benthic fauna are influenced by several factors such as life cycles, chemical defenses, or algal architecture (Chemello and Milazzo 2002; Hauser et al. 2006; Veiga et al. 2014; Thiriet et al. 2016). In the present system too, apart from the dominance of M. galloprovincialis at all sites, the three Cystoseira species supported diversified molluscan assemblages. Cystoseira amentacea and C. compressa hosted a similar number of taxa, although $C$. amentacea always accounted for a relatively higher number of individuals. This may be due to the longer thalli of this species that would offer a wider area for colonization. The maximum total number of species at the 'regional' scale, however, as well as the maximum number of species per sampling unit, were found at Scannella for $C$. crinita. The same patterns were displayed by the diversity indexes. Moreover, the number of individuals associated with $C$. crinita at Scannella was comparable to that of the other two algal species at the same site. This, together with its high percentage of unshared species within the sampling site, indicates that the $C$. crinita-associated malacofauna was relatively more heterogeneous in terms of species composition.

With respect to the species-specific patterns of molluscan assemblages, the shape of the k-dominance curves built including M. galloprovincialis may suggest a poor structure of molluscan assemblages associated with the three Cystoseira species. After the removal of $M$. galloprovincialis, however, the same curves were initially characterized by low dominance and slowly reached the asymptote, suggesting that the Cystoseira-associated assemblages were actually well diversified, but that such a feature was masked by the disproportionately abundant mussels. 
Among the 52 molluscan taxa censused, only 12 were shared among the three habitatforming species, much less were shared between only two of them, and six, 16, and one species were exclusive of $C$. compressa, $C$. amentacea, and $C$. crinita, respectively. This clearly shows that even congeneric and syntopic taxa may not support benthic fauna in the same way. The presence of five rissoid taxa (accounting for $50 \%$ of Rissoidae) associated with C. amentacea was especially notable. Unfortunately, the available information on the malacofauna associated with this species, sometimes mentioned in the literature under its synonyms/varieties $C$. stricta or C. spicata (Bellan-Santini 1962, 1969; Tiganus 1984; Chemello 1986; Menioui 1992b; Ergen and Çinar 1994; Mačić and Svirčev 2014), is scant. Moreover, no authors have yet formally compared faunal assemblages between different Cystoseira taxa. The only partial exceptions were provided by Bellan-Santini (1969) and Chemello (1986), who just reported faunal lists associated with each investigated algal taxon. Such a knowledge gap crucially hinders any possibility to compare the present data with previous findings.

\section{Conclusions}

There is increasing evidence of a worldwide decline of canopy-forming algae (Eriksson et al. 2002; Thibaut et al. 2005; Coleman et al. 2008; Smale and Wernberg 2013; Bianchi et al. 2014), whose loss may trigger cascade effects on associated biodiversity and ecosystem services (Wilson et al. 2008; Schiel and Lilley 2011). Due to this, the conservation status of Cystoseira species has become a main management priority within the European Water Framework Directive in the Mediterranean basin. In spite of that, the overall knowledge of such canopies is still limited, and here we not only filled a gap by providing essential basic information on the patterns of diversity of Cystoseira species and their associated molluscan biota at Ischia Island (Italy, Mediterranean Sea), but also first suggest a species-specific role as habitat-formers being played by different sympatric Cystoseira taxa. 
Although our study is intrinsically unable to elucidate the mechanisms involved, the broader implications of our findings are numerous. First, the knowledge of natural patterns of distribution and abundance of Cystoseira species would provide a reference for detecting changes due to anthropogenic disturbance (Chapman et al. 1995; Fraschetti et al. 2005), which is of particular importance in an area subject to a wide number of human activities of potential impact such as the Gulf on Naples (Bertocci et al., 2019). Second, such knowledge is essential to optimize sampling and experimental designs suited to capture, in the most comprehensive way possible, the actual variability of the target organisms, thus avoiding possibly incorrect ecological interpretations (Underwood 1993; Benedetti-Cecchi et al. 2001). Finally, and strictly linked to the previous points, our findings have an important management value in the context of the growing awareness of spatial and temporal heterogeneity as a criterion for designing and assessing the effectiveness of MPAs. Specifically, it is acknowledged that the zoning and implementation of an effective MPA should guarantee a complete and accurate representation of the relevant scales of variation of the target populations and assemblages, as well as of their abiotic and biological drivers (Benedetti-Cecchi et al. 2003). In such a context, we here suggest an implementation of the local Regno di Nettuno MPA that should rely on the present data and rank at the maximum level of protection the whole infralittoral fringe hosting the above-mentioned Cystoseira species, thus taking into account their among-sites variation to include a representative sample of such target organisms. By contrast, the inclusion of just one or a few sites, possibly chosen a priori based on whatever criterion, would likely result in an oversimplified picture of the real situation and, eventually, a loss of considerable biodiversity.

\section{Acknowledgments}

Vincenzo Rando (Italy) and Bruno Iacono (Italy) helped during fieldwork. Giuseppe Fasulo (Italy), Jakov Prkić (Croatia), and Luigi Romani (Italy) assisted with the taxonomic 
identifications. Andrej Jaklin (Croatia), Melih Ertan Çinar (Turkey), and Pasqualina Fiorentino (Italy) provided relevant literature upon request.

\section{Disclosure statement}

No potential conflict of interest was reported by the authors.

\section{Funding}

This work has been partially funded by the Italian Flagship Project RITMARE - The Italian Research for the Sea.

\section{References}

Anderson, M. J. (2001). A new method for non-parametric multivariate analysis of variance. Austral Ecology 26(1), 32-46. doi:10.1111/j.1442-9993.2001.01070.pp.x

Ballesteros, E. (1992). Els vegetals i la zonació litoral: espècies, comunitats i factors que influeixen en la seva distribució. Institut d' Estudis Catalans, Barcelona: Spain.

Ballesteros, E., Torras, X., Pinedo, S., García, M., Mangialajo, L., de Torres, M. (2007). A new methodology based on littoral community cartography dominated by macroalgae for the implementation of the European Water Framework Directive. Marine Pollution Bulletin 55(1-6), 172-180. doi:10.1016/j.marpolbul.2006.08.038

Bedini, R., Bonechi, L., Piazzi, L. (2014). Mobile epifaunal assemblages associated with Cystoseira beds: comparison between areas invaded and not invaded by Lophocladia lallemandii. Scientia Marina 78(3), 425-432. doi:10.3989/scimar.03995.28B 
Bellan-Santini, D. (1962). Étude floristique et faunistique de quelques peuplements infralittoraux sur substrat rocheux. Recueil des travaux de la Station marine d'Endoume 26(41), 237-298.

Bellan-Santini, D. (1964). Étude qualitative et quantitative du peuplement à Cystoseira crinita Bory (Note Préliminaire). Recueil des travaux de la Station marine d'Endoume 34(50), 249261.

Bellan-Santini, D. (1969). Contribution a l'étude des peuplement infralittoraux sur substrat rocheux (Etude qualitative et quantitative de la frange supérieure). Recueil des travaux de la Station marine d'Endoume 63(47), 9-292.

Benedetti-Cecchi, L., Cinelli, F. (1996). Patterns of disturbance and recovery in littoral rock pools: nonhierarchical competition and spatial variability in secondary succession. Marine Ecology Progress Series 135, 145-161.

Benedetti-Cecchi, L., Nuti, S., Cinelli, F. (1996). Analysis of spatial and temporal variability in interactions among algae, limpets and mussels in low-shore habitats on the west coast of Italy. Marine Ecology Progress Series 144, 87-96.

Benedetti-Cecchi, L., Pannacciulli, F., Bulleri, F., Moschella, P. S., Airoldi, L., Relini, G., Cinelli, F. (2001). Predicting the consequences of anthropogenic disturbance: large-scale effects of loss of canopy algae on rocky shores. Marine Ecology Progress Series 214, 137150. doi:10.3354/meps 214137

Benedetti-Cecchi, L., Airoldi, L., Fraschetti, S., Terlizzi, A. (2003). Capitolo 14. Metodi sperimentali per la valutazione di influenze antropiche su popolamenti ed ambienti marini costieri. Biologia Marina Mediterranea 10(suppl.), 485-508.

Bertocci, I., Dell'Anno, A., Musco, L., Gambi, C., Saggiomo, V., Cannavacciuolo, M., Lo Martire, M., Passarelli, A., Zazo, G., Danovaro, R. (2019). Multiple human pressures in coastal habitats: variation of meiofaunal assemblages associated with sewage discharge in a 
post-industrial area. Science of the Total Environment 655, 1218-1231. doi:10.1016/j.scitotenv.2018.11.121

Bianchi, C. N., Pronzato, R., Cattaneo-Vietti, R., Benedetti-Cecchi, L., Morri, C., Pansini, M., Chemello, R., Milazzo, M., Fraschetti, S., Terlizzi, A., Peraino, A., Salvati, E., Benzoni, F., Calcinai, B., Cerrano, C., Bavestrello, G. (2003). Capitolo 6. I fondi duri. Biologia Marina Mediterranea 10(suppl.), 199-232.

Bianchi, C. N., Corsini-Foka, M., Morri, C., Zenetos, A. (2014). Thirty years after: dramatic change in the coastal marine ecosystems of Kos Island (Greece), 1981-2013. Mediterranean Marine Science 15(2), 482-497. doi:10.12681/mms.678

Blanfuné, A., Boudouresque, C. F., Verlaque, M., Thibaut, T. (2016). The fate of Cystoseira crinita, a forest-forming Fucale (Phaeophyceae, Stramenopiles), in France (North Western Mediterranean Sea). Estuarine, Coastal and Shelf Science 181, 196-208. doi:10.1016/j.ecss.2016.08.049

Boudouresque, C. F., Belsher, T. (1979). Une méthode de determination de l'aire minimale qualitative. Rapport et Proces Verbaux de la Commission Internationale pour l'Exploration Scientifique de la Mer Méditerranée 25-26(4), 273-275.

Buia, M. C., Chiarore, A., Mulas, M., Porzio, L. (2013). Historical changes in algal diversity in the Gulf of Naples. In: Proceedings of the $10^{\text {th }}$ Global Congress on ICM: lessons learned to address new challenges, EMECS 2013 - MEDCOAST 2013 Joint Conference. Marmaris, Turkey, p 837-846.

Bulleri, F., Benedetti-Cecchi, L., Acunto, S., Cinelli, F., Hawkins, S. J. (2002). The influence of canopy algae on vertical patterns of distribution of low-shore assemblages on rocky coasts in the northwest Mediterranean. Journal of Experimental Marine Biology and Ecology 267(1), 89-106. doi:10.1016/S0022-0981(01)00361-6

Chapman, M. G., Underwood, A. J., Skilleter, G. A. (1995). Variability at different spatial scales between a subtidal assemblage exposed to the discharge of sewage and two control 
assemblages. Journal of Experimental Marine Biology and Ecology 189(1-2), 103-122. doi:10.1016/0022-0981(95)00017-L

Chiarore, A., Patti, F. P. (2013). Molluscs community characteristic of brown algae Sargassum vulgare (Agardh) along Ischia island. Notiziario S.I.M. 31(2), 10-11.

Chemello, R. (1986). Studio della malacofauna costiera dell'isola di Ustica (Gastropoda). Lavori S.I.M. 1986 - Atti del I Congresso S.I.M. 22, 51-76.

Chemello, R., Milazzo, M. (2002). Effect of algal architecture on associated fauna: some evidence from phytal molluscs. Marine Biology 140(5), 981-990. doi:10.1007/s00227-0020777-X

Cheminée, A., Sala, E., Pastor, J., Bodilis, P., Thiriet, P., Mangialajo, L., Cottalorda, J. - M., Francour, P. (2013). Nursery value of Cystoseira forests for Mediterranean rocky reef fishes. Journal of Experimental Marine Biology and Ecology 442, 70-79. doi:10.1016/j.jembe.2013.02.003

Clarke, K. R. (1990). Comparisons of dominance curves. Journal of Experimental Marine Biology and Ecology 138(1-2), 143-157. doi:10.1016/0022-0981(90)90181-B

Clarke, K. R. (1993). Non-parametric multivariate analyses of changes in community structure. Australian Journal of Ecology 18, 117-143. doi:10.1111/j.1442-9993.1993.tb00438.x

Coleman, M. A., Kelaher, B. P., Steinberg, P. D., Millar, A. J. K. (2008). Absence of a large brown macroalga on urbanized rocky reefs around Sydney, Australia, and evidence for historical decline. Journal of Phycology 44, 897-901. doi:10.1111/j.15298817.2008.00541.x

Coll, M., Piroddi, C., Steenbeek, J., Kaschner, K., Lasram, F. B. R., Aguzzi, J., Ballesteros, E., Bianchi, C. N., Corbera, J., Dailianis, T., Danovaro, R., Estrada, M., Froglia, C., Galil, B., Gasol, J. M., Gertwagen, J., Gil, J., Guilhaumon, F., Kesner-Reyes, K., Kitsos, M. S., Koukouras, A., Lampadariou, N., Laxamana, E., de la Cuadra, C. M. L., Lotze, H. K., Martin, D., Mouillot, D., Oro, D., Raicevich, S., Rius-Barile, J., Saiz-Salinas, J. I., San 
Vicente, C., Somot, S., Templado, J., Turon, X., Vafidis, D., Villanueva, R., Voultsiadou, E. (2010). The Biodiversity of the Mediterranean Sea: Estimates, Patterns, and Threats. PLoS One 5, e11842. doi:10.1371/journal.pone.0011842

Cormaci, M., Furnari, G., Catra, M., Alongi, G., Giaccone, G. (2012). Flora marina bentonica del Mediterraneo: Phaeophyceae. Bollettino dell'Accademia Gioenia di Scienze Naturali di Catania 45(375), 1-508.

Ergen, Z., Çinar, M. E. (1994). Ege Denizi’nde dağılım gösteren Cystoseira fasiesinin kalitatif ve kantitatif yönden araştirilmasi. XII. Ulusal Biyoloji Kongresi, Edirne IV, 138-149.

Eriksson, B. K., Johansson, G., Snoeijs, P. (2002). Long-term changes in the microalgal vegetation of the inner Gullmar Fiord, Swedish Skagerrak coast. Journal of Phycology 38, 284-296. doi:10.1046/j.1529-8817.2002.00170.x

Falace, A., Zanelli, E., Bressan, G. (2005). Morphological and reproductive phenology of Cystoseira compressa (Esper) Gerloff \& Nizamuddin (Fucales, Fucophyceae) in the Gulf of Trieste (North Adriatic Sea). Annales Series Historia Naturalis 15(1), 71-78.

Falace, A., Tamburello, L., Guarnieri, G., Kaleb, S., Papa, L., Fraschetti, S. (2018). Effects of a glyphosate-based herbicide on Fucus virsoides (Fucales, Ochrophyta) photosynthetic efficiency. Environmental Pollution 243(B), 912-918. doi:10.1016/j.envpol.2018.08.053

Fraschetti, S., Giangrande, A., Terlizzi, A., Miglietta, M., Della Tommasa, L., Boero, F. (2002). Spatio-temporal variation of hydroids and polychaetes associated with Cystoseira amentacea (Fucales: Phaeophyceae). Marine Biology 140(5), 949-957. doi:10.1007/s00227001-0770-9

Fraschetti, S., Terlizzi, A., Benedetti-Cecchi, L. (2005). Patterns of distribution of marine assemblages from rocky shore: evidence of relevant scales of variation. Marine Ecology Progress Series 296, 13-29. doi:10.3354/meps296013

Gambi, M. C. (2002). Spatio-temporal distribution and ecological role of polychaete borers of Posidonia oceanica (L.) Delile scales. Bulletin of Marine Science 71(3), 1323-1331. 
Gambi, M. C., Lorenti, M., Russo, G. F., Scipione, M. B., Zupo, V. (1992). Depth and seasonal distribution of some groups of the vagile fauna of the Posidonia oceanica leaf stratum: structural and trophic analyses. Marine Ecology 13, 17-39. doi:10.1111/j.14390485.1992.tb00337.x

Gambi, M. C., Conti, G., Bremec, C. S. (1996). Biodiversity and environmental factors in the benthic coastal systems: an approach with polychaete populations of Cymodocea nodosa meadows. Biologia Marina Mediterranea 3(1), 40-45.

Giaccone, G., Alongi, G., Pizzuto, F., Cossu, A. V. L. (1994). La Vegetazione marina bentonica fotofila del Mediterraneo: II. Infralitorale e Circalitorale. Proposte di aggiornamento. Bollettino dell'Accademia Gioenia di Scienze Naturali 27(346), 111-157.

Gianni, F., Bartolini, F., Pey, A., Laurent, M., Martins, G. M., Airoldi, L., Mangialajo, L. (2017). Threats to large brown algal forests in temperate seas: the overlooked role of native herbivorous fish. Scientific Reports 7, 6012. doi:10.1038/s41598-017-06394-7

Gofas, S., Moreno, D., Salas, C. (2012) (Coords.). Moluscos marinos de Andalucía. Vol. I [pp. i-xvi y 1-342] and II [pp. i-xii y 343-809]. Servicio de Publicaciones e Intercambio Científico, Universidad de Málaga: Málaga.

Grech, D., Patti, F. P., Chiarore, A., Mulas, M., Buia, M. C. (2015). Coastal transformation and marine habitat loss. In: Proceedings of the $12^{\text {th }}$ International Conference on the Mediterranean Coastal Environment - MEDCOAST 2015. Varna, Bulgaria, p 271-281.

Gros, C. (1978). Le genre Cystoseira sur la côte des Albères. Répartition - Écologie Morphogenèse. Ph.D. thesis, Université P. et M. Curie, Paris VI.

Hauser, A., Attrill, M. J., Cotton, P. A. (2006). Effects of habitat complexity on the diversity and abundance of macrofauna colonising artificial kelp holdfasts. Marine Ecology Progress Series 325, 93-100. doi:10.3354/meps325093 
Hoffmann, L., Renard, R., Demoulin, V. (1992). Phenology, growth and biomass of Cystoseira balearica in Calvi (Corsica). Marine Ecology Progress Series 80(2-3), 249-254. http://www.jstor.org/stable/24826612

Iveša, L., Djakovac, T., Devescovi, M. (2016). Long-term fluctuations in Cystoseira populations along the west Istrian Coast (Croatia) related to eutrophication patterns in the northern Adriatic Sea. Marine Pollution Bulletin 106, 162-173. doi:10.1016/j.marpolbul.2016.03.010

Kocataş, A. (1978). İzmir Körfezi kayalık sahillerinin bentik formları üzerinde kalitatif ve kanitatif araştirmalar. Ege Üniversitesi Fen Fakültesi Monografiler Serisi 12, 1-93.

Lolas, A., Antoniadou, C., Vafidis, D. (2018). Spatial variation of molluscan fauna associated with Cystoseira assemblages from a semi-enclosed gulf in the Aegean Sea. Regional Studies in Marine Sciences 19, 17-24. doi:10.1016/j.rsma.2018.03.003

Mačić, V., Svirčev, Z. (2014). Macroepiphytes on Cystoseira species (Phaeophyceae) on the coast of Montenegro. Fresenius Environmental Bulletin 23(1), 29-34.

Mangialajo, L., Chiantore, M., Cattaneo-Vietti, R. (2008). Loss of fucoid algae along a gradient of urbanisation, and structure of benthic assemblages. Marine Ecology Progress Series 358, 63-74. doi:10.3354/meps07400

Mancuso, F. P., Strain, E. M. A., Piccioni, E., De Clerck, O., Sarà, G., Airoldi, L. (2018). Status of vulnerable Cystoseira populations along the Italian infralittoral fringe, and relationships with environmental and anthropogenic variables. Marine Pollution Bulletin 129(2), 762-771. doi:10.1016/j.marpolbul.2017.10.068

Mann, K. H. (1973). Seaweeds: their productivity and strategy for growth. Science 182(4116), 975-981. doi:10.1126/science.182.4116.975

Massa-Gallucci, A., Cigliano, M., Lattanzi, L., Patti, F. P., Buia, M. C., Gambi, M. C. (2006). Zoobenthos associato a fondi a rodoliti (Corallinales) dell'Isola d'Ischia (Mare Tirreno). Biologia Marina Mediterranea 13(2), 193-194. 
Mazzella, L., Scipione, M. B., Buia, M. C. (1989). Spatio-temporal distribution of algal and animal communities in a Posidonia oceanica meadow. Marine Ecology 10(2), 107-129. doi:10.1111/j.1439-0485.1989.tb00069.x

Mazzella, L., Buia, M. C., Gambi, M. C., Lorenti, M., Russo, G. F., Scipione, M. B., Zupo, V. (1992). Plant-animal trophic relationships in the Posidonia oceanica ecosystem of the Mediterranean Sea: a review. In: Plant-animal interactions in the marine benthos. Clarendon Press, Oxford, p 165-187.

Menioui, M. (1992a). Étude faunistique et écologique des côtes rocheuses du Maroc. III Peuplement à Cystoseira fimbriata. Bulletin de l'Institut Scientifique Rabat 16, 87-93.

Menioui, M. (1992b). Étude faunistique et écologique des côtes rocheuses du Maroc. IV Peuplement à Cystoseira stricta. Bulletin de l'Institut Scientifique Rabat 16, 94-101.

Micheli, F., Benedetti-Cecchi, L., Gambaccini, S., Bertocci, I., Borsini, C., Osio, G. C., Romano, F. (2005). Cascading human impacts, marine protected areas, and the structure of Mediterranean reef assemblages. Ecological Monographs 75(1), 81-102. doi:10.1890/034058

Milazzo, M., Chemello, R., Badalamenti, F., Riggio, S. (2000). Molluscan assemblages associated with photophilic algae in the Marine Reserve of Ustica Island (Lower Tyrrhenian Sea, Italy). Italian Journal of Zoology 67, 287-295. doi:10.1080/11250000009356326

Orfanidis, S. (2007). Comments on the development of new macroalgal indices to assess water quality within the Mediterranean Sea. Marine Pollution Bulletin 54(5), 626-627. doi:10.1016/j.marpolbul.2007.01.004

Orfanidis, S., Panayotidis, P., Stamatis, N. (2001). Ecological evaluation of transitional and coastal waters: A marine benthic macrophytes-based model. Mediterranean Marine Science 2(2), 45-65. doi:10.12681/mms.266 
Perkol-Finkel, S., Airoldi, L. (2010). Loss and recovery potential of marine habitats: an experimental study of factors maintaining resilience in subtidal algal forests at the Adriatic Sea. PLoS ONE 5(5), e10791. doi:10.1371/journal.pone.0010791

Piazzi, L., Bonaviri, C., Castelli, A., Ceccherelli, G., Costa, G., Curini-Galletti, M., Langeneck, J., Manconi, R., Montefalcone, M., Pipitone, C., Rosso, A., Pinna, S. (2018). Biodiversity in canopy-forming algae: Structure and spatial variability of the Mediterranean Cystoseira assemblages. Estuarine, Coastal and Shelf Science 207, 132-141. doi:10.1016/j.ecss.2018.04.001

Pitacco, V., Orlando-Bonaca, M., Mavrič, B., Popovič, A., Lipej, L. (2014). Mollusc fauna associated with the Cystoseira algal associations in the Gulf of Trieste (Northern Adriatic Sea). Mediterranean Marine Science 15(2), 225-238. doi:10.12681/mms.466

Poulicek, M. (1985). Les mollusques des biocénoses à algues photophiles en Méditerranée: II. Analyse du peuplement. Cahiers de Biologie Marine 26, 127-136.

Poursanidis, D., Koutsoubas, D., Arvanitidis, C., Chatzigeorgiou, G. (2016). ReefMedMol: Mollusca from the infralittoral rocky shores - the biocoenosis of photophilic algae - in the Mediterranean Sea. Biodiversity Data Journal 4, e7516. doi:10.3897/BDJ.4.e7516

Poursanidis, D., Chatzigeorgiou, G., Charalampos, D., Koutsoubas, D., Arvanitis, C. (2019). Testing the robustness of a coastal biodiversity data protocol in the Mediterranean: insights from the molluskan assemblages from the sublittoral macroalgae communities. Hydrobiologia 826(1), 159-172. doi:10.1007/s10750-018-3725-6

Rueda, J. L., Gofas, S., Urra, J., Salas, C. (2009). A highly diverse molluscan assemblage associated with eelgrass beds (Zostera marina L.) in the Alboran Sea: Micro-habitat preference, feeding guilds and biogeographical distribution. Scientia Marina 73(4), 679700. doi:10.3989/scimar.2009.73n4679

Russo, A. R. (1997). Epifauna living on sublittoral seaweeds around Cyprus. Hydrobiologia 344(1-3), 169-179. doi:10.1023/A:1002970714963 
Russo, G. F., Fresi, E., Vinci, D., Chessa, L. A. (1983). Malacofauna di strato foliare delle praterie di Posidonia oceanica (L.) Delile intorno all'isola d'Ischia (golfo di Napoli): analisi strutturale del popolamento estivo in rapporto alla profondità ed alla esposizione. Nova Thalassia 6(suppl.), 655-661.

Sala, E., Ballesteros, E., Dendrinos, P., Di Franco, A., Ferretti, F., Foley, D., Fraschetti, S., Friedlander, A., Garrabou, J., Güçlüsoy, H. (2012). The structure of Mediterranean rocky reef ecosystems across environmental and human gradients, and conservation implications. PLoS ONE 7(2), e32742. doi:10.1371/journal.pone.0032742

Sales, M., Ballesteros, E. (2012). Seasonal dynamics and annual production of Cystoseira crinita (Fucales: Ochrophyta)-dominated assemblages from the northwestern Mediterranean. Scientia Marina 76(2), 391-401. doi:10.3989/scimar.03465.16D

Sales, M., Ballesteros, E., Anderson, M. J., Iveša, L., Cardona, E. (2012). Biogeographical patterns of algal communities in the Mediterranean Sea: Cystoseira crinita-dominated assemblages as a case study. Journal of Biogeography 39(1), 140-152. doi:10.1111/j.13652699.2011.02564.X

Scaperrotta, M., Bartolini, S., Bogi, C. (2009-2016). Accrescimenti. Stadi di accrescimento dei molluschi marini del Mediterraneo. Stages of Growth of the Marine Molluscs of the Mediterranean Sea. Vol. I [2009: 167 pp], Vol. II [2010: 176 pp], Vol. III [2011: 184 pp], Vol. IV [2011: 184 pp], Vol. V [2013: 192 pp], Vol. VI [2014: 192 pp], Vol. VII [2015: 192 pp], Vol. VIII [2016: 208 pp]. L'Informatore Piceno: Ancona.

Schiel, D. R., Foster, M. S. (2006). The population biology of large brown seaweeds: ecological consequences of multiphase life histories in dynamic coastal environments. Annual Review of Ecology, Evolution, and Systematics 37, 343-372. http://www.jstor.org/stable/30033836 
Schiel, D. R., Lilley, S. A. (2011). Impacts and negative feedbacks in community recovery over eight years following removal of habitat-forming macroalgae. Journal of Experimental Marine Biology and Ecology 407, 108-115. doi:10.1016/j.jembe.2011.07.004

Scipione, M. B., Gambi, M. C., Lorenti, M., Russo, G., Zupo, V. (1996). Vagile fauna of the leaf stratum of Posidonia oceanica and Cymodocea nodosa in the Mediterranean Sea. In: Seagrass biology: Proceedings of an International Workshop, Rottnest Island, Western Australia, p. 249-260.

Smale, D. A., Wernberg, T. (2013). Extreme climatic event drives range contraction of a habitat-forming species. Proceedings of the Royal Society B 280, 20122829. doi:10.1098/rspb.2012.2829

Solis-Weiss, V., Aleffi, F., Bettoso, N., Rossin, P., Orel, G., Fonda-Umani, S. (2004). Effects of industrial and urban pollution on the benthic macrofauna in the Bay of Muggia (industrial port of Trieste, Italy). Science of the Total Environment 328(1-3), 247-263. doi:10.1016/j.scitotenv.2004.01.027

Thibaut, T., Pinedo, S., Torras, X., Ballesteros, E. (2005). Long-term decline of the populations of Fucales (Cystoseira spp. and Sargassum spp.) in the Alberes coast (France, Northwestern Mediterranean). Marine Pollution Bulletin 50(12), 1472-1489. doi:10.1016/j.marpolbul.2005.06.014

Thibaut, T., Blanfuné, A., Boudouresque, C. F., Verlaque, M. (2015). Decline and local extinction of Fucales in the French Riviera: the harbinger of future extinctions? Mediterranean Marine Science 16(1), 206-224. doi:10.12681/mms.1032

Thiriet, P. D., Di Franco, A., Cheminée, A., Guidetti, P., Bianchimani, O., Basthard-Bogain, S., Cottalorda, J. - M., Arceo, H., Moranta, J., Lejeusne, P., Francour, P., Mangialajo, L. (2016). Abundance and diversity of crypto- and necto-benthic coastal fish are higher in marine forests than in structurally less complex macroalgal assemblages. PLOS ONE 11(10), e0164121. doi:10.1371/journal.pone.0164121 
Ţigănuş, V. (1984). Contributions à la connaissance de la faune associée aux macrophytes de la côte libyenne de la méditerranée. Travaux du Museum d'Histoire Naturelle "Grigore Antipa” 26, 61-68.

Trainito, E., Doneddu, M. (2014). Nudibranchi del Mediterraneo. 2a edizione, riveduta ed ampliata. Il Castello: Milano.

Underwood, A. J. (1993). The mechanisms of spatially replicated sampling programmes to detect environmental impact in a variable world. Austral Ecology 18(1), 99-116. doi:10.1111/j.1442-9993.1993.tb00437.x

Underwood, A. J. (1997). Experiments in Ecology: Their Logical Design and Interpretation Using Analysis of Variance. Cambridge University Press: Cambridge.

Veiga, P., Rubal, M., Sousa-Pinto, I. (2014). Structural complexity of macroalgae influences epifaunal assemblages associated with native and invasive species. Marine Environmental Research 101, 115-123. doi:10.1016/j.marenvres.2014.09.007

Vergés, A., Alcoverro, T., Ballesteros, E. (2009). Role of fish herbivory in structuring the vertical distribution of canopy algae Cystoseira spp. in the Mediterranean Sea. Marine Ecology Progress Series 375, 1-11. doi:10.3354/meps07778

Wilson, S. K., Fisher, R., Pratchett, M. S., Graham, N. A. J., Dulvy, N. K., Turner, R. A., Cakacaka, A., Polunin, N. V. C., Rushton, S. P. (2008). Exploitation and habitat degradation as agents of change within coral reef fish communities. Global Change Biology 14, 2796-2800. doi:10.1111/j.1365-2486.2008.01696.x

WoRMS Editorial Board. (2018). World Register of Marine Species. Available from http://www.marinespecies.org at VLIZ. Accessed 2018-10-05. doi:10.14284/170

Zavodnik, D. (1965). Prispevek k poznavanju naselja Cystoseira barbata (Good. \& Wood.) C. Ag. v severnem jadranu. Bioloski Vestnik 13, 87-101. 
Table 1. Analysis of variance (ANOVA) testing for differences in percentage cover, biomass, number, and mean length of thalli of three Cystoseira species $(C$. amentacea, C. compressa, and $C$. crinita) $(\mathrm{Cy})$ at two times (June-July 2015 and June-July 2016) (Ti) and six sampling sites (Castello Aragonese, San Pancrazio, Sant'Angelo, Scannella, Punta Imperatore, and Punta Caruso) (Si). * p<0.05, ** $\mathbf{p}<0.01, * * * \mathbf{p}<0.001$.

\begin{tabular}{|c|c|c|c|c|c|c|c|c|c|c|}
\hline & & \multicolumn{2}{|c|}{$\%$ cover } & \multicolumn{2}{|c|}{ biomass } & \multicolumn{2}{|c|}{ \# thalli } & \multicolumn{2}{|c|}{ mean length } & \multirow[b]{2}{*}{ Denominator } \\
\hline Source of variation & $\mathrm{df}$ & MS & $F$ & MS & $F$ & MS & $F$ & MS & $F$ & \\
\hline Cystoseira species & 2 & 55071.1 & - & 5842.5 & - & 32.07 & - & 834.88 & - & no test \\
\hline $\mathrm{Ti} \times \mathrm{Cy}$ & 2 & 662.7 & 1.40 & 7.4 & 0.05 & 0.36 & $4.29 *$ & 17.46 & 1.10 & $\mathrm{Ti} \times \mathrm{Cy} \times \mathrm{Si}$ \\
\hline $\mathrm{Ti} \times \mathrm{Si}$ & 5 & 414.7 & 1.37 & 112.9 & 1.04 & 0.21 & $3.13 *$ & 12.69 & $2.64 *$ & Residual \\
\hline $\mathrm{Cy} \times \mathrm{Si}$ & 10 & 2590.5 & $5.46^{* *}$ & 500.9 & $3.52 *$ & 0.97 & $11.39 * * *$ & 106.03 & $6.69 * *$ & $\mathrm{Ti} \times \mathrm{Cy} \times \mathrm{Si}$ \\
\hline Cochran's test & & $C=0.131$ & & $C=0.212$ & & $C=0.186$ & & $C=0.166$ & & \\
\hline Transformation & & None & & None & & $\operatorname{Ln}(x+1)$ & & None & & \\
\hline
\end{tabular}


Table 2. Molluscan assemblage found in Cystoseira belts in Ischia, with feeding guilds (FG), distribution groups (DG), and percentages of frequency of occurrence (\%F) and dominance (\%D). Abbreviations used. Sites: CA - Castello Aragonese; SP - San Pancrazio; SA - Sant'Angelo; SC - Scannella; PI Punta Imperatore; PC - Punta Caruso. Feeding guilds: C - carnivores; D - deposit feeders; E - ectoparasites and specialised carnivores; FF - filter feeders; MG - micrograzers and/or mesograzers; AG - macroalgae grazers. Distribution groups: A - species shared among the three Cystoseira taxa; B species exclusive for $C$. compressa; $\mathrm{C}$ - species exclusive for $C$. amentacea; $\mathrm{D}$ - species exclusive for $\boldsymbol{C}$. crinita; $\mathrm{E}$ - species shared between $C$. compressa and C. amentacea; $\mathrm{F}$ - species shared between $C$. compress $a$ and $C$. crinita $; \mathrm{G}$ - species shared between $C$. amentacea and $C$. crinita.

\begin{tabular}{|c|c|c|c|c|c|c|c|c|c|c|c|}
\hline Family & Species & $\mathbf{F G}$ & $\mathbf{D G}$ & $\mathbf{C A}$ & SP & $\mathbf{S A}$ & $\mathbf{S C}$ & PI & PC & $\% \mathbf{F}$ & $\% \mathbf{D}$ \\
\hline \multirow{2}{*}{ Acanthochitonidae } & Acanthochitona crinita (Pennant, 1777) & MG & $\mathrm{C}$ & & + & & & & & 1.28 & 0.09 \\
\hline & Acanthochitona fascicularis (Linnaeus, 1767) & MG & A & + & & & + & & & 3.85 & 0.28 \\
\hline \multirow{2}{*}{ Patellidae } & Patella caerulea Linnaeus, 1758 & MG & B & + & & & & & & 2.56 & 0.28 \\
\hline & Patella ulyssiponensis Gmelin, 1791 & MG & $\mathrm{C}$ & & & & & & + & 1.28 & 0.09 \\
\hline \multirow{2}{*}{ Fissurellidae } & Diodora graeca (Linnaeus, 1758) & MG & B & & & & & & + & 1.28 & 0.09 \\
\hline & Fissurella nubecula (Linnaeus, 1758) & MG & $\mathrm{C}$ & & & & + & & & 1.28 & 0.09 \\
\hline \multirow[t]{3}{*}{ Scissurellidae } & Sinezona cingulata (O.G. Costa, 1861 ) & $\mathrm{D}$ & A & + & & + & + & + & + & 29.50 & 3.23 \\
\hline & Clanculus cruciatus (Linnaeus, 1758) & MG & G & & & + & + & & & 3.85 & 0.37 \\
\hline & Clanculus jussieui (Payraudeau, 1826) & MG & $\mathrm{F}$ & & & & + & & + & 2.56 & 0.18 \\
\hline \multirow[t]{3}{*}{ Trochidae } & Phorcus turbinatus (Born, 1778) & MG & A & & + & + & + & + & + & 15.38 & 1.48 \\
\hline & Steromphala adansonii (Payraudeau, 1826) complex & MG & $\mathrm{D}$ & & & & + & & & 1.28 & 0.09 \\
\hline & Steromphala varia (Linnaeus, 1758) & MG & $\mathrm{B}$ & & & & + & & & 1.28 & 0.09 \\
\hline Phasianellidae & Tricolia pullus (Linnaeus, 1758) & MG & $\mathrm{E}$ & + & + & & & & & 3.85 & 0.28 \\
\hline Cerithiidae & Bittium latreillii (Payraudeau, 1826) & MG & G & & + & & + & & & 2.56 & 0.18 \\
\hline Triphoridae & Marshallora adversa (Montagu, 1803) & MG & B & & & & + & & & 1.28 & 0.09 \\
\hline \multirow{2}{*}{ Cingulopsidae } & Eatonina fulgida (J. Adams, 1797) & MG & $\mathrm{E}$ & + & + & + & + & & & 5.13 & 0.55 \\
\hline & Eatonina pumila (Monterosato, 1884) & MG & A & + & + & + & + & + & + & 58.97 & 12.38 \\
\hline \multirow{10}{*}{ Rissoidae } & Alvania cf. cancellata (da Costa, 1778) & MG & $\mathrm{C}$ & + & & & & & & 1.28 & 0.09 \\
\hline & Alvania discors (T. Allan, 1818) & MG & $\mathrm{C}$ & & & + & & & & 1.28 & 0.09 \\
\hline & Alvania cf. lanciae (Calcara, 1845) & MG & $\mathrm{C}$ & & & & & + & & 1.28 & 0.09 \\
\hline & Crisilla beniamina (Monterosato, 1884) & MG & $\mathrm{C}$ & & & + & & + & & 2.56 & 0.28 \\
\hline & Obtusella macilenta (Monterosato, 1880) & MG & $\mathrm{C}$ & & & + & & & & 1.28 & 0.37 \\
\hline & Rissoa guerinii Récluz, 1843 & MG & A & + & + & + & + & & & 11.54 & 1.11 \\
\hline & Rissoa lia (Monterosato, 1884) & MG & G & + & + & + & + & & & 8.97 & 2.31 \\
\hline & Rissoa variabilis (Megerle von Mühlfeld, 1824) & MG & A & + & & + & + & + & & 12.28 & 0.92 \\
\hline & Setia ambigua (Brugnone, 1873) & MG & $\mathrm{C}$ & & + & + & & & & 2.56 & 0.18 \\
\hline & Setia fusca (Philippi, 1841) & MG & $\mathrm{C}$ & & & & + & & & 1.28 & 0.09 \\
\hline Anabathridae & Pisinna glabrata (Megerle von Mühlfeld, 1824) & MG & G & & & + & + & & & 3.85 & 1.11 \\
\hline Barleeiidae & Barleeia unifasciata (Montagu, 1803) & MG & A & & + & + & + & & & 10.26 & 1.20 \\
\hline \multirow{2}{*}{ Vermetidae } & Thylaeodus rugulosus (Monterosato, 1878) & $\mathrm{FF}$ & A & + & + & + & + & + & + & 34.62 & 6.93 \\
\hline & Dendropoma cristatum (Biondi, 1859) & $\mathrm{FF}$ & A & + & & + & + & + & + & 16.67 & 2.12 \\
\hline Columbellidae & Columbella rustica (Linnaeus, 1758) & MG & G & & + & & & + & & 3.85 & 2.12 \\
\hline Raphitomidae & Raphitoma sp. & $\mathrm{C}$ & $\mathrm{C}$ & & & & & + & & 1.28 & 0.09 \\
\hline \multirow{2}{*}{ Rissoellidae } & Rissoella diaphana (Alder, 1848) & MG & $\mathrm{C}$ & & + & & & & & 1.28 & 0.09 \\
\hline & Rissoella inflata (Monterosato, 1880) & MG & G & & + & & + & & & 2.56 & 0.18 \\
\hline Pisaniidae & Pisania striata (Gmelin, 1791) & $\mathrm{C}$ & $\mathrm{C}$ & & & & & + & & 1.28 & 0.09 \\
\hline Omalogyridae & Ammonicera fischeriana (Monterosato, 1869) & MG & $\mathrm{E}$ & & + & + & & + & + & 10.26 & 0.74 \\
\hline Aplysiidae & Aplysia cf. parvula Mörch, 1863 & AG & $\mathrm{C}$ & & & & & & + & 1.28 & 0.09 \\
\hline Hancockiidae & Hancockia uncinata (Hesse, 1872) & $\mathrm{E}$ & $\mathrm{E}$ & + & + & + & & + & & 6.41 & 2.31 \\
\hline \multirow{2}{*}{ Dotidae } & Doto cervicenigra Ortea \& Bouchet, 1989 & $\mathrm{E}$ & $\mathrm{E}$ & + & + & + & + & + & + & 14.10 & 11.18 \\
\hline & Doto rosea Trinchese, 1881 & $\mathrm{E}$ & G & & & & + & + & & 3.85 & 0.55 \\
\hline Eubranchidae & Eubranchus cf. tricolor Forbes, 1838 & $\mathrm{E}$ & $\mathrm{C}$ & & + & & & & & 1.28 & 0.09 \\
\hline Trinchesiidae & Trinchesia sp. & $\mathrm{E}$ & $\mathrm{E}$ & + & + & + & + & + & + & 21.79 & 3.51 \\
\hline \multirow{4}{*}{ Mytilidae } & Modiolus barbatus (Linnaeus, 1758) & FF & $\mathrm{E}$ & & + & & & + & + & 5.13 & 0.55 \\
\hline & Musculus costulatus (Risso, 1826) & $\mathrm{FF}$ & A & + & + & + & + & + & + & 69.23 & 28.92 \\
\hline & Mytilaster solidus Monterosato, 1883 & $\mathrm{FF}$ & A & + & + & + & + & + & + & 55.13 & 10.91 \\
\hline & Mytilus galloprovincialis (Lamarck, 1819) & FF & A & + & + & + & + & + & + & 100.00 & ---- \\
\hline Anomiidae & Anomia ephippium Linnaeus, 1758 & $\mathrm{FF}$ & $\mathrm{C}$ & & + & & & & & 1.28 & 0.09 \\
\hline Carditidae & Cardita calyculata (Linnaeus, 1758) & FF & $\mathrm{F}$ & + & + & & + & & & 5.13 & 0.65 \\
\hline Lasaeidae & Lasaea rubra (Montagu, 1803) & $\mathrm{FF}$ & $\mathrm{B}$ & & & + & + & & & 2.56 & 0.18 \\
\hline Cardiidae & Parvicardium exiguum (Gmelin, 1791) & FF & $\mathrm{C}$ & & + & & & & & 1.28 & 0.09 \\
\hline Hiatellidae & Hiatella arctica (Linnaeus, 1767) & FF & B & & + & + & + & & & 6.41 & 0.74 \\
\hline
\end{tabular}


Table 3. Permutational multivariate analysis of variance (PERMANOVA) testing for differences in the composition of molluscan assemblages associated with three Cystoseira species (C. amentacea, $C$. compressa and $C$. crinita) (Cy) at two times (June-July 2015 and June-July 2016) (Ti) and six sampling sites (Castello Aragonese, San Pancrazio, Sant'Angelo, Scannella, Punta Imperatore, and Punta Caruso) (Si). Significant effects are indicated in bold.

\begin{tabular}{|c|c|c|c|c|c|}
\hline \multicolumn{6}{|c|}{ Untransformed data } \\
\hline Source of variation & $\mathrm{df}$ & MS & pseudo- $F$ & $\mathrm{p}$ & \# unique perm. \\
\hline Time & 1 & 1966.8 & 0.76 & 0.633 & 999 \\
\hline Cystoseira species & 2 & 37548.0 & 6.02 & 0.001 & 999 \\
\hline Site & 5 & 5886.7 & 2.27 & 0.004 & 997 \\
\hline $\mathrm{Ti} \times \mathrm{Cy}$ & 2 & 3062.8 & 0.96 & 0.469 & 999 \\
\hline $\mathrm{Ti} \times \mathrm{Si}$ & 5 & 2597.5 & 1.21 & 0.166 & 998 \\
\hline $\mathrm{Cy} \times \mathrm{Si}$ & 10 & 3703.1 & 1.16 & 0.237 & 999 \\
\hline $\mathrm{Ti} \times \mathrm{Cy} \times \mathrm{Si}$ & 10 & 3180.1 & 1.48 & 0.007 & 998 \\
\hline Residual & 72 & 2154.8 & & & \\
\hline \multicolumn{6}{|c|}{ Presence - Absence data } \\
\hline Source of variation & $\mathrm{df}$ & MS & pseudo- $F$ & $\mathrm{p}$ & \# unique perm. \\
\hline Time & 1 & 5191.1 & 1.86 & 0.038 & 999 \\
\hline Cystoseira species & 2 & 34056.0 & 4.58 & 0.001 & 998 \\
\hline Site & 5 & 4405.8 & 1.58 & 0.037 & 998 \\
\hline $\mathrm{Ti} \times \mathrm{Cy}$ & 2 & 3898.5 & 1.45 & 0.073 & 998 \\
\hline $\mathrm{Ti} \times \mathrm{Si}$ & 5 & 2784.7 & 1.25 & 0.072 & 997 \\
\hline $\mathrm{Cy} \times \mathrm{Si}$ & 10 & 4127.6 & 1.53 & 0.008 & 998 \\
\hline $\mathrm{Ti} \times \mathrm{Cy} \times \mathrm{Si}$ & 10 & 2693.5 & 1.21 & 0.058 & 994 \\
\hline Residual & 72 & 2226.4 & & & \\
\hline
\end{tabular}


Table 4. Analysis of variance (ANOVA) testing for differences in the species richness $(S)$, the Shannon index $\left(H^{\prime}\right)$ and the reciprocal Simpson index (1/D) of molluscan assemblages associated with three Cystoseira species $(C$. amentacea, $C$. compressa, and $C$. crinita) $(C y)$ at two times (June-July 2015 and June-July 2016) (Ti) and six sampling sites (Castello Aragonese, San Pancrazio, Sant'Angelo, Scannella, Punta Imperatore, and Punta Caruso) $(\mathrm{Si}) . * \mathrm{p}<0.05, * * \mathrm{p}<0.01$.

\begin{tabular}{|c|c|c|c|c|c|c|c|c|}
\hline & & $\mathbf{S}$ & & $\mathbf{H}^{\prime}$ & & 1/D & & \\
\hline Source of variation & $\mathrm{df}$ & MS & $F$ & $\mathrm{MS}$ & $F$ & $\mathrm{MS}$ & $F$ & Denominator \\
\hline Time & 1 & 0.75 & 0.14 & 0.0001 & 0.00 & 0.02 & 0.16 & $\mathrm{Ti} \times \mathrm{Si}$ \\
\hline Cystoseira species & 2 & 240.56 & - & 0.0917 & - & 8.90 & - & no test \\
\hline Site & 5 & 12.28 & 2.27 & 0.0671 & 3.83 & 1.21 & $8.38 *$ & $\mathrm{Ti} \times \mathrm{Si}$ \\
\hline $\mathrm{Ti} \times \mathrm{Cy}$ & 2 & 3.86 & 0.79 & 0.0213 & 1.49 & 0.22 & 1.44 & $\mathrm{Ti} \times \mathrm{Cy} \times \mathrm{Si}$ \\
\hline $\mathrm{Ti} \times \mathrm{Si}$ & 5 & 5.42 & 1.54 & 0.0175 & $4.09 * *$ & 0.14 & $2.51 *$ & Residual \\
\hline $\mathrm{Cy} \times \mathrm{Si}$ & 10 & 18.25 & $3.76 *$ & 0.0345 & 2.40 & 0.99 & $6.49 * *$ & $\mathrm{Ti} \times \mathrm{Cy} \times \mathrm{Si}$ \\
\hline $\mathrm{Ti} \times \mathrm{Cy} \times \mathrm{Si}$ & 10 & 4.86 & 1.38 & 0.0143 & $3.35^{* *}$ & 0.15 & $2.66 * *$ & Residual \\
\hline Residual & 72 & 3.52 & & 0.0043 & & 0.06 & & \\
\hline Cochran's test & & $C=0.113$ & & $C=0.170$ & & $C=0.808^{* *}$ & & \\
\hline Transformation & & None & & Square $\operatorname{root}(\mathrm{x}+1)$ & & None & & \\
\hline
\end{tabular}


Table 5. Contribution $\left(\delta_{i}\right)$ of individual taxa from molluscan assemblages (presence vs. absence data) to the dissimilarity within each of three Cystoseira species. Only taxa cumulatively contributing $\geq 90 \%$ to total dissimilarity are included. Values of $\delta_{i} / \operatorname{SD}\left(\delta_{i}\right) \geq 1$ indicate that the contribution of a taxon to percentage dissimilarity was consistent among pairwise comparisons of samples.

\begin{tabular}{|c|c|c|c|c|c|}
\hline \multicolumn{6}{|c|}{ Cystoseira compressa } \\
\hline Taxon & Frequency $(\%)$ & $\delta_{i}$ & $\delta_{i} \%$ & cumul. \% & $\delta_{i} / \mathrm{SD}\left(\delta_{i}\right)$ \\
\hline Mytilus galloprovincialis & 100 & 22.93 & 45.86 & 45.86 & 3.36 \\
\hline Mytilaster solidus & 58 & 6.23 & 12.46 & 58.32 & 0.66 \\
\hline Musculus costulatus & 53 & 6.08 & 12.16 & 70.48 & 0.60 \\
\hline Eatonina pumila & 47 & 5.07 & 10.13 & 80.61 & 0.56 \\
\hline Thylaeodus rugulosus & 39 & 3.44 & 6.89 & 87.50 & 0.45 \\
\hline Sinezona cingulata & 22 & 1.98 & 3.95 & 91.45 & 0.33 \\
\hline \multicolumn{6}{|c|}{ Cystoseira amentacea } \\
\hline Taxon & Frequency $(\%)$ & $\delta_{i}$ & $\delta_{i} \%$ & cumul. \% & $\delta_{i} / \mathrm{SD}\left(\delta_{i}\right)$ \\
\hline Mytilus galloprovincialis & 100 & 17.94 & 33.54 & 33.54 & 3.37 \\
\hline Musculus costulatus & 89 & 13.69 & 25.59 & 59.12 & 1.62 \\
\hline Eatonina pumila & 72 & 9.21 & 17.21 & 76.33 & 0.94 \\
\hline Mytilaster solidus & 56 & 6.63 & 12.40 & 88.74 & 0.79 \\
\hline Sinezona cingulata & 31 & 1.54 & 2.88 & 91.61 & 0.34 \\
\hline \multicolumn{6}{|c|}{ Cystoseira crinita } \\
\hline Taxon & Frequency $(\%)$ & $\delta_{i}$ & $\delta_{i} \%$ & cumul. \% & $\delta_{i} / \mathrm{SD}\left(\delta_{i}\right)$ \\
\hline Mytilus galloprovincialis & 17 & 16.98 & 44.58 & 44.58 & 3.36 \\
\hline Musculus costulatus & 14 & 11.71 & 30.74 & 75.32 & 1.20 \\
\hline Sinezona cingulata & 8 & 2.90 & 7.60 & 82.92 & 0.48 \\
\hline Dendropoma cristatum & 6 & 1.21 & 3.18 & 86.10 & 0.26 \\
\hline Thylaeodus rugulosus & 6 & 1.11 & 2.92 & 89.02 & 0.26 \\
\hline Eatonina pumila & 6 & 1.03 & 2.69 & 91.71 & 0.26 \\
\hline
\end{tabular}




\section{LEGEND TO FIGURES}

Fig. 1. Map illustrating (A) the location of the study area within the Mediterranean Sea, and (B) the six sampling sites around Ischia Island $(\mathrm{CA}=$ Castello Aragonese, $\mathrm{SP}=\mathrm{San}$ Pancrazio, $\mathrm{SA}=$ Sant' Angelo, $\mathrm{SC}=$ Scannella, $\mathrm{PI}=$ Punta Imperatore, $\mathrm{PC}=$ Punta Caruso).

Fig. 2. Mean $(+\mathrm{SE})$ percentage cover $(\mathrm{A}, \mathrm{n}=6)$, biomass $(\mathrm{B}, \mathrm{n}=6)$ and number of thalli $(\mathrm{C}-\mathrm{a}$, $\mathrm{n}=6$, and $\mathrm{C}-\mathrm{b}, \mathrm{n}=18$ ) of three Cystoseira species. Different letters above bars represent significantly different means (SNK test: only within-site comparisons are appropriate in panels A, B and C-a; only within-time comparisons are appropriate in panel C-b). Abbreviations as in Figure 1.

Fig. 3. Mean $(+\mathrm{SE}, \mathrm{n}=3)$ thallus length of three Cystoseira species at two times and six sampling sites. Different letters above bars represent significantly different means (SNK test: only within-site comparisons are appropriate). Abbreviations as in Figure 1.

Fig. 4. Mean $(+\mathrm{SE})$ values of richness $(A, n=6)$, Shannon index $(B, n=3)$ and reciprocal Simpson index $(\mathrm{C}, \mathrm{n}=3)$ of molluscan assemblages associated with three Cystoseira species. Different letters above bars represent significantly different means (SNK test: only within-site comparisons are appropriate). Abbreviations as in Figure 1.

Fig. 5. $k$-dominance curves of molluscan assemblages (A, C and E: Mytilus galloprovincialis included, B, D and F: M. galloprovincialis excluded) associated with three Cystoseira species at six sampling sites. Cumulative dominance values reported as percentages. Abbreviations as in Figure 1. Note that different plots are on different scales. 


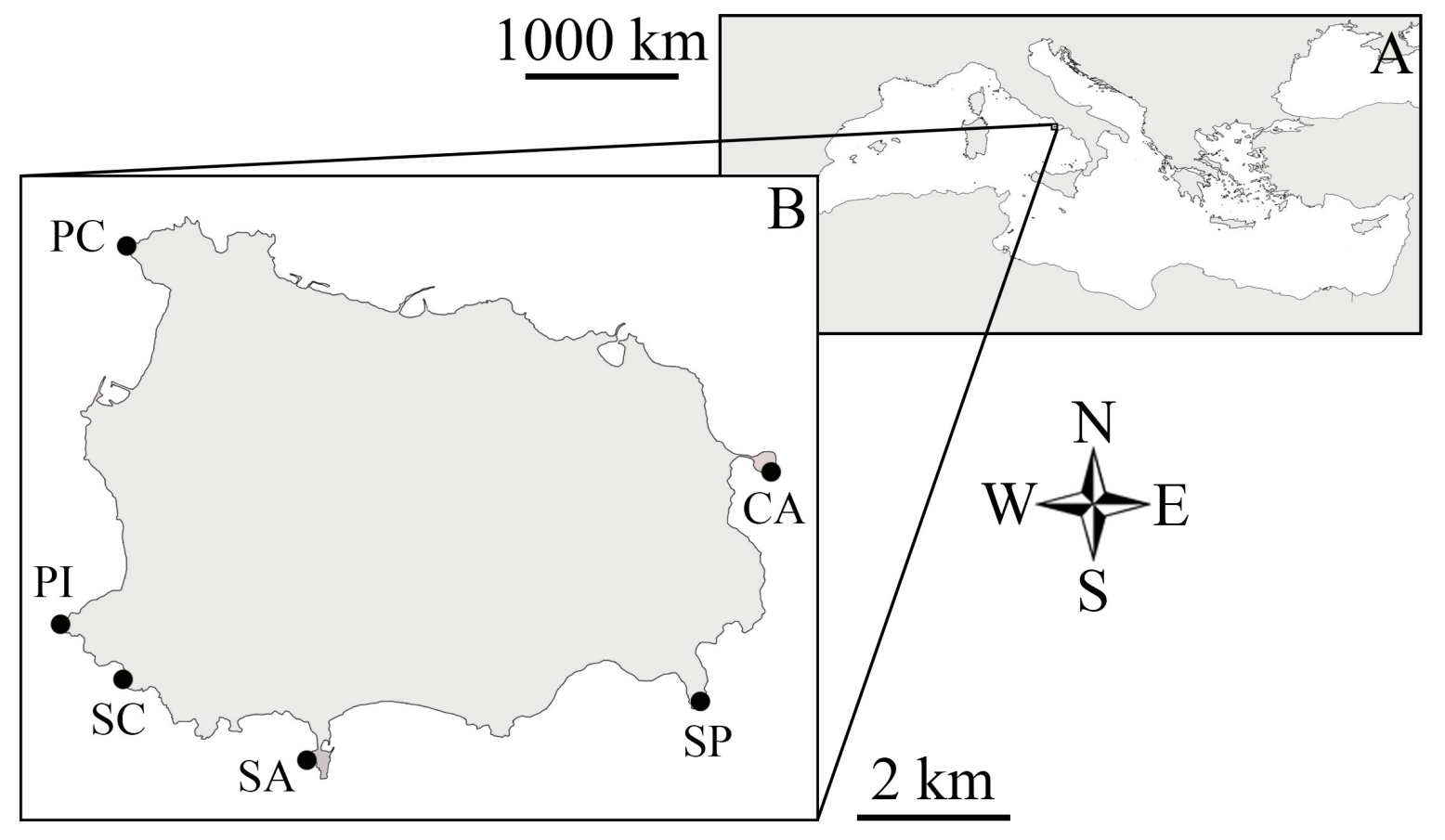

Fig. 1 


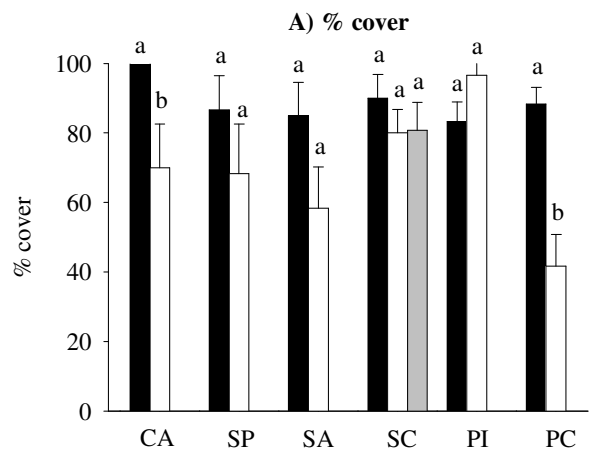

Cystoseira compressa

$\square$ Cystoseira amentacea

$\square$ Cystoseira crinita

B) Biomass

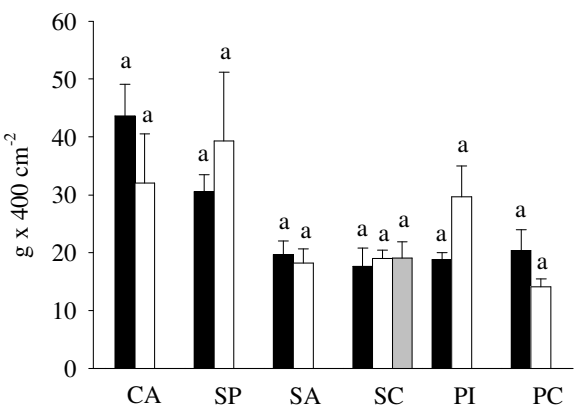

C-a) Number of thalli

C-b) Number of thalli

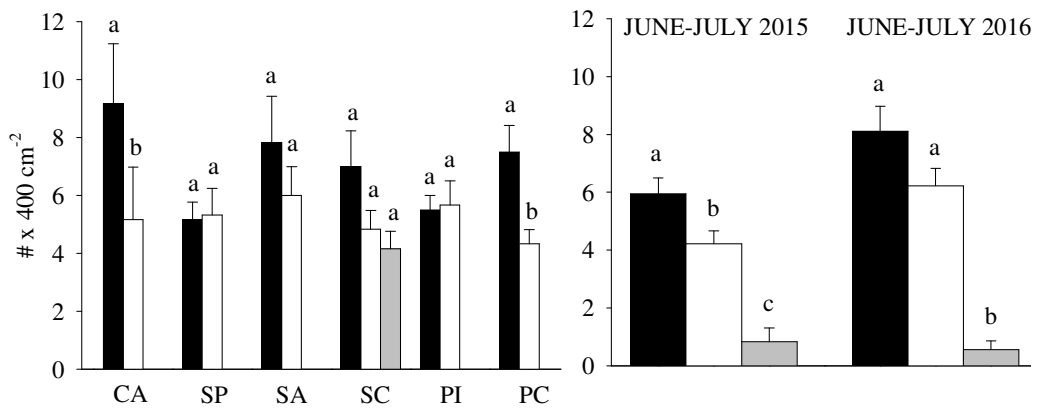

Fig. 2 


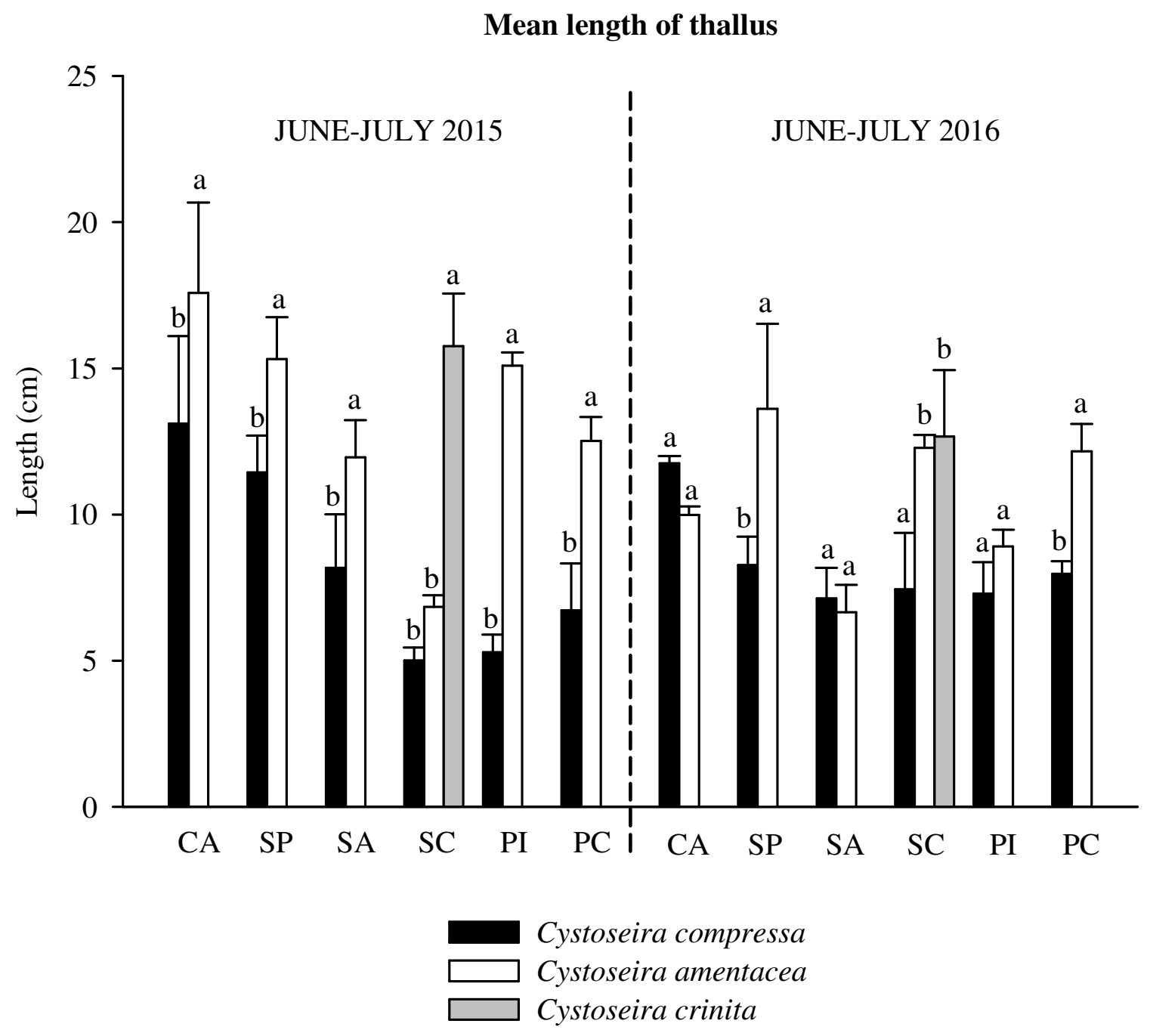

Fig. 3 
A) Richness (S)
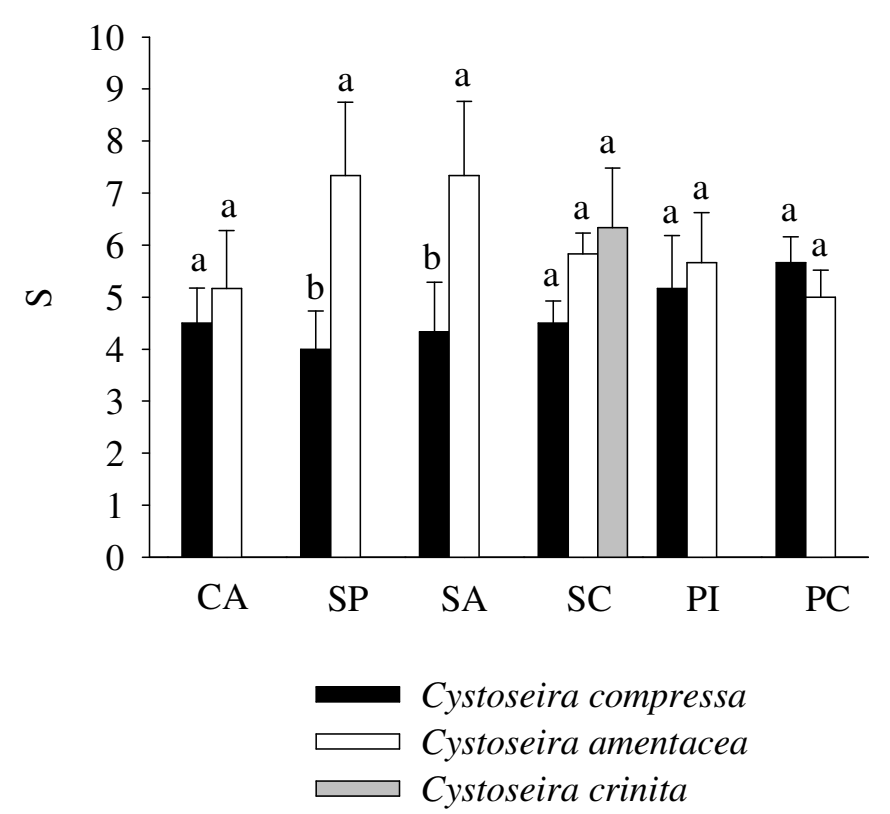

B) Shannon index $\left(\mathrm{H}^{\prime}\right)$

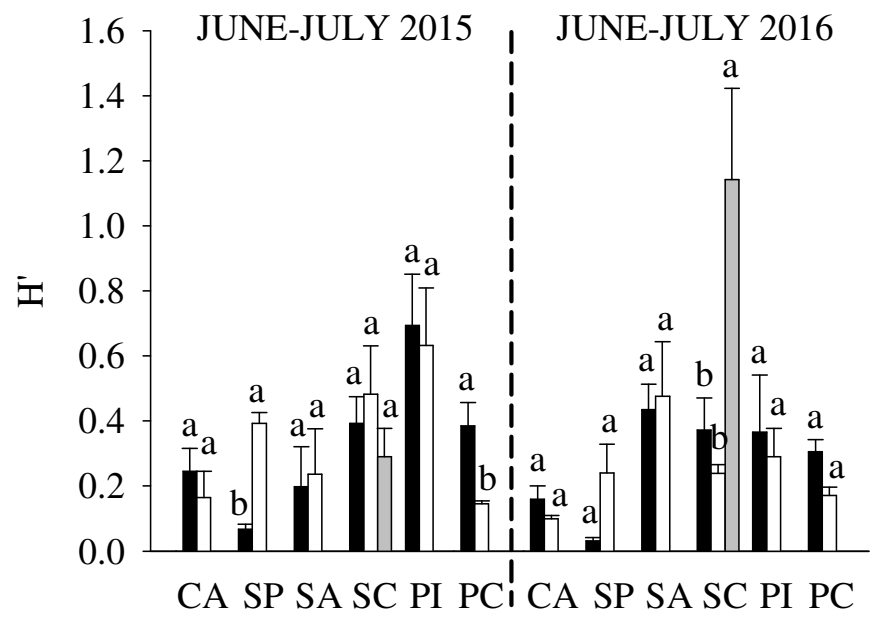

C) Reciprocal Simpson index (1/D)

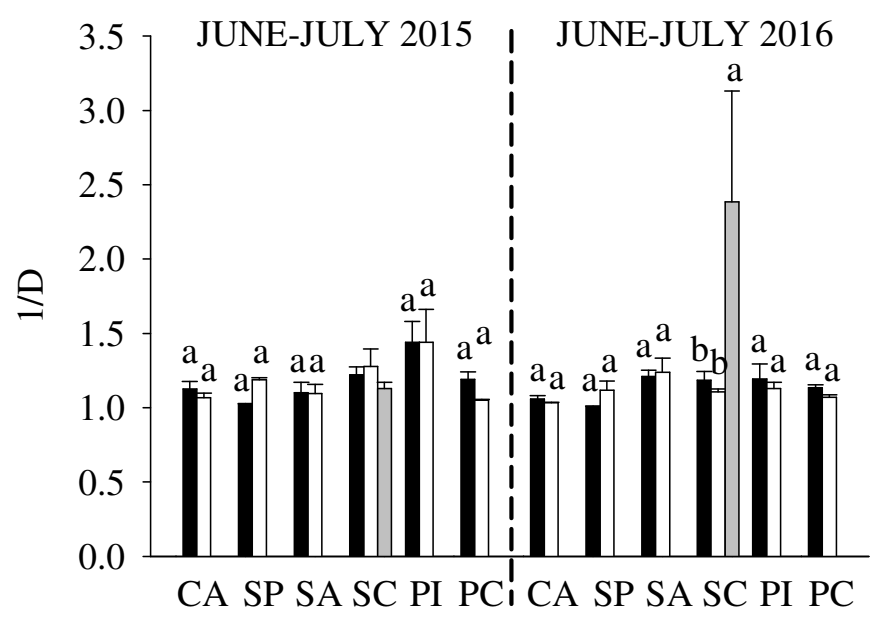

Fig. 4 


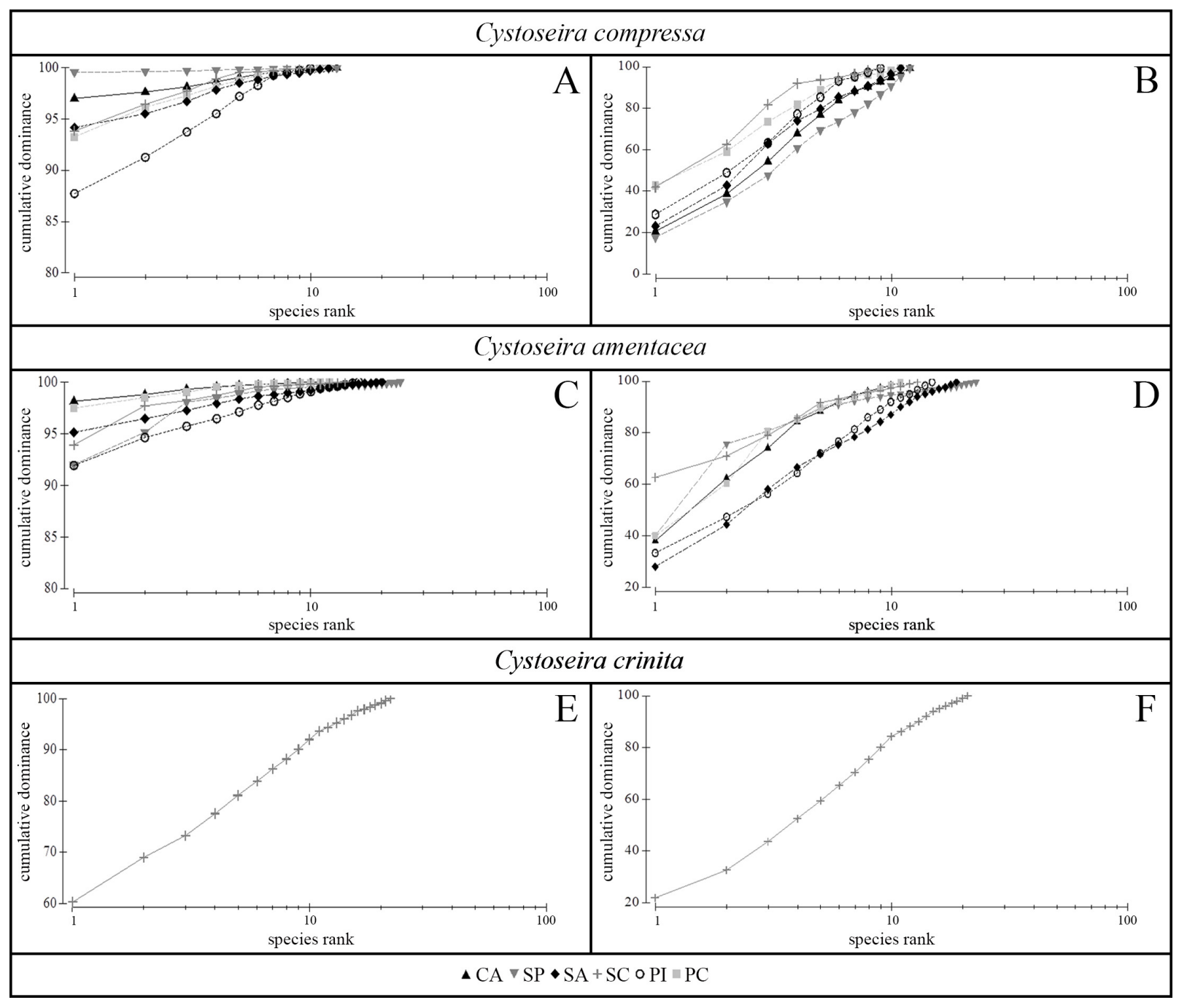

Figure 5 